\title{
MATH GAME FOR EARLY CHILDHOOD
}

\author{
Sri Maryani \\ IKIP Siliwangi Cimahi \\ sri.230869@gmail.com
}

\begin{abstract}
The purpose of this study was to introduce mathematical games in the form of introducing geometric forms through the game of tangram in early childhood in the Istiqamah Bandung Playgroup The type of research used is classroom action research, carried out in collaboration with class teachers. The research subjects were 13 children, consisting of 7 boys and 6 girls. The object of research is the introduction of geometric forms through the game of tangram. The technique of collecting data uses observation, interviews and performance. The data analysis technique uses qualitative analysis. The indicator of success in this study is if the percentage of the ability to recognize geometric shapes in children has reached $81 \%$ with very good criteria. The results of the study showed a gradual increase in the introduction of geometric forms through the game of tangram. The introduction of geometric forms can be seen from the indicators mentioning geometric shapes, designating geometric shapes, making more than one geometric shape and telling the geometric shapes they are made. Mathematical games in early childhood through the introduction of geometric shapes on the tangram game in the implementation of the Pre-action on the indicators mention geometric shapes $41.5 \%$, and in Cycle II it increases to $93 \%$, the indicators designate geometric shapes in the implementation of the Pre-action 35\%, Cycle II increased to $90 \%$, the indicator made more than one Prat geometry form, $37.5 \%$, Cycle II increased to $85, \%$. As well as on the indicators telling geometric shapes that made pre-action $41.5 \%$ in the second cycle to $87.5 \%$.
\end{abstract}

Keywords: Math game, Early Childhood

\section{INTRODUCTION}

Education is a conscious and planned effort to create a learning atmosphere and learning process so that students actively develop their potential to have religious spiritual strength, self-control, personality, intelligence, noble character and skills needed by themselves, society, nation and country. Non-formal education or what is now known as public education is education held for citizens who need educational services that function as substitutes, enhancers, and / or complementary formal education in order to support lifelong education, one form of non-formal education services namely children's education early age.

Early childhood is in the most rapid stages of physical and mental growth and development. Early childhood is the most important and basic initial period throughout the span of growth and development of human life because all the potential of children develop very quickly, even this early age is known as the golden age. Learning for young children is fun, by providing learning that makes children impressed and meaningful from the various experiences they have experienced. So, in the process of learning early childhood the teacher 
must have a specific strategy for the ongoing learning process. Early childhood education is the educational level of children from the age of 0-6 years, at this level children are given various stimuli for the growth and development of children in the golden age so that they have the readiness to enter a higher level of education. According to" Permendikbud No. 137 the Year 2014, the scope of development according to the level of children includes 6 aspects of religious and moral values; physical motor; cognitive; language; social-emotional; and art “(Sumardi, Nur, \& Sa' diyyah, 2017)

Development and growth in children must be stimulated properly, so that their developmental tasks can develop optimally. One of the development tasks that must be stimulated is cognitive development by introducing objects that are around the child. In its growth, children cannot be separated from objects around them. Since childhood, they have known the closest objects, the shape of the object is the same as geometry, for example coins, cabinets, tables, books, balls, or other objects that are used to meet the needs of everyday life and play.

The world of children is a playful world. Playing is an activity that is spontaneous and fun for every child, by playing each child will feel relaxed, happy and not depressed. Playing activities for a child naturally will give satisfaction and pleasure. Play activities can be carried out in the family and school environment. Playing at home with family members and peers, children do spontaneously because they are loved, and often without specific goals. Playing in a school environment can be useful as a medium in learning and stimuli or stimuli aimed at increasing the ability of all aspects of early childhood development

The low ability to recognize geometric shapes in children Playgroup (PG) Istiqamah there are several causes, namely, the use of learning media used is limited, the teacher does not introduce various types of geometry. In addition, the teacher only uses blackboard media and pictures of various geometric shapes, as a result of the child's ability to recognize geometric shapes not yet well mastered. Children are still confused when mentioning various geometric shapes, namely the shape of a rectangle, a triangle, and a circle. The presentation in the learning method used is a lecture, the teacher only tells the story in front of him explaining the image of the gemetri consequently when the teaching and learning activities are not conducive, many children tell their friends, and some play alone, as a result the teaching and learning process is not optimal.

Introducing geometric shapes in early childhood can be done through various games, the ability of children to recognize, point, mention and collect objects around them based on geometric shapes. Introducing geometric forms in early childhood starts from building geometric concepts, namely by identifying the characteristics of geometric shapes. the same circle and position itself in a space. "Children can understand the notion of space when the child is aware of his position when connected with structuring objects around him. Children learn about places and positions, such as: above, below, on, inside, outside. In addition, children also learn about the definition of distance, such as: close, far and so forth" (Lisa, 2017)

One form of game to recognize geometric forms is tangram. Tangram can be called a constructive game because in the game it involves a process of building or creating a form. Expected through the game of tangram of the children of the Playgroup in Istiqamah to be able to recognize various geometric shapes with fun. 


\section{METHOD}

This research was conducted in the even semester of the academic year 2018/2019. The place for conducting research at playgrup Istiqamah, Bandung Wetan District, Bandung City. The subjects studied were playgroup students, amounting to 13 children consisting of 7 boys and 6 girls. While the object under study is a mathematical game, namely the introduction of geometric forms through tangram games. The type of research used is classroom action research (Classroom action research) "namely research conducted by teachers in the classroom or in the school where he teaches with an emphasis on refinement or improvement of process and practical learning" (Arikunto, 2010). While the purpose of classroom action research "is to solve real problems that occur in the classroom and increase the real activity of teachers in their professional development activities" (Ketut et al., 2014). data collection uses observational methods of activities carried out on students in the teaching and learning process. Each activity observed was categorized into the appropriate qualities, namely the ability of Undeveloped Children (*), Beginning to Develop (**), Developing Expectations $(* * *)$, and Developing Very Well (****), the study was conducted in two cycles. As for the model of action in this study, Jhon Elliot's model is shown in the picture below

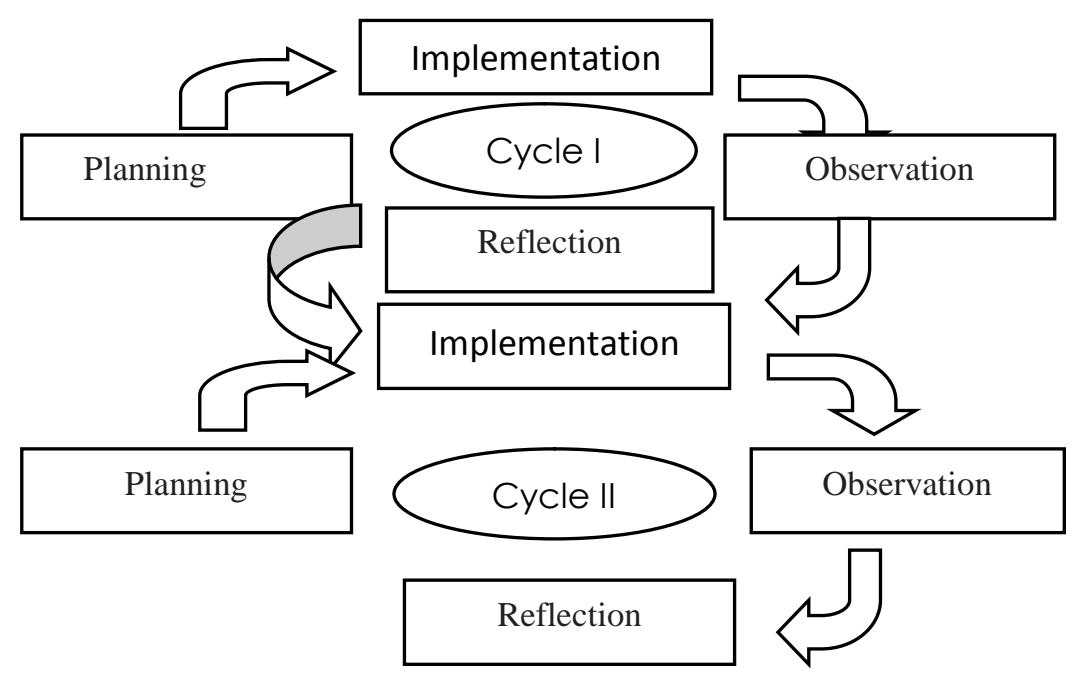

Picture 1. Jhon Elliot's model is shown in the picture below

The descriptive analysis method is used to determine the high level of low introduction of geometric shapes through tangram games converted into five-point reference scoring (PRS) (Ketut et al., 2014) poured table below: 
Table 1. Reference assessment table

\begin{tabular}{cc}
\hline Presentation & Introduction Geometry \\
\hline $81-100 \%$ & Very good \\
$61-80 \%$ & Good \\
$41-60 \%$ & Enough \\
$21-40 \%$ & Less \\
$0-20 \%$ & Less once \\
\hline
\end{tabular}

The formulation of indicators is used as a measure of the success of the research conducted. Performance indicators are performance formulations that will be used as a reference in determining the success or effectiveness of research. Indicators of success in this study regarding the ability to recognize geometric shapes in children in the Play Group through tangram games will be seen from the learning process that is in accordance with the predetermined indicators of success. The indicator of success in this study is characterized by the increased ability to recognize geometric forms in children. The researcher determines the indicator of success, namely the average percentage or $81 \%$ with very good criteria

The research instrument grid is used to facilitate the research process. In this study, researchers became the main instrument that went directly to the field to collect the data needed. Besides the researcher as the main instrument, the researcher will also use an auxiliary instrument in the form of an observation sheet. After the data in this study was collected, the data analysis was then carried out. The purpose of data analysis or processing is to make generalizations about the properties, conditions, or relationships that are specific, so that the conditions, traits, or relationships that are general in nature are obtained. The observation instrument in this study is

Table 2. Observation instrument

\begin{tabular}{|l|l|l|l|l|l|}
\hline \multirow{2}{*}{ No } & \multicolumn{1}{|c|}{ Value } & \multicolumn{3}{|c|}{ Statement } \\
\cline { 4 - 6 } & & $*$ & $* *$ & $* * *$ & $* * * *$ \\
\hline 1 & Mention the geometric shapes & & & & \\
\hline 2 & Shows geometric shapes & & & & \\
\hline 3 & Make more than one geometry shape & & & & \\
\hline 4 & Telling the shape of the geometry he made & & & & \\
\hline
\end{tabular}

\section{RESULTS AND DISCUSSION}

\section{Results}

This research is to find out whether the activities of playing tangram as an effort for the introduction of geometric forms in early childhood in the Istiqamah Playgroup. This research was conducted in two cycles, because at the end of the second cycle the results of the expected achievements in students were seen in the introduction of geometric forms in early childhood through tangram games.

To find out the initial conditions the researcher made preliminary observations of the research subjects to obtain the basic criteria of this study, the researcher carried out the test of students' 
abilities by observing classroom learning through activities when learning lasted several days before conducting research. Besides that, the researcher conducted an interview with the class teacher about the introduction of geometric forms to the children who were the subjects of the study, and the researchers conducted documentation studies through monthly reports of children each month given to parents by the school. From the results of preliminary observations, interviews and study of the documentation, it was seen that the introduction of geometric forms had not yet developed optimally. The researcher conducted pre-cycle observations to find out the students' initial abilities. The results of the study obtained the following data

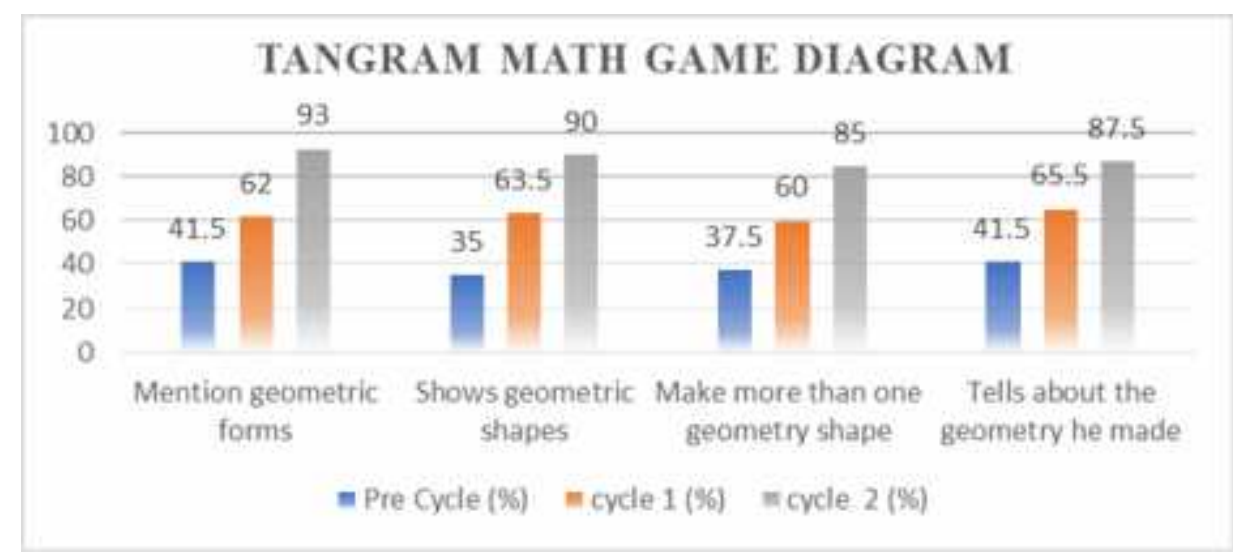

Picture 2. Action result diagram

From the pre-cycle capacity assessment, it can be analyzed that the initial ability of the Play group (PG) Istiqamah in the activity mentioned geometric forms obtained as a percentage of $41.5 \%$, from 13 children of Istiqamah Play Group (PG) only 5 children who could mention geometric shapes. Most or 58.5\% of children still need guidance in mentioning geometric forms. This means that in the activity of mentioning geometric forms still requires teacher guidance, the child still needs to be improved in his ability to mention geometric forms through exercises that can be done and guided by the teacher in the learning process. In the ability to show geometric forms only $35 \%$ of children can show geometric forms correctly, $65 \%$ of 13 children still need guidance, training and motivation in showing geometric forms. In the category Making more than one geometry form made up of a small number of 13 children, $37.5 \%$ who have the ability to make more than one geometric shape made, $62.5 \%$ of children must be guided and trained in making more than one geometric shape was made. In the category of telling geometric shapes that he made clearly, there were $41.5 \%$ or a small number of children who were able to tell the geometric shapes they made clearly, there were still a large proportion of $58.5 \%$ of children who still needed guidance and motivation.

\section{Discussion}

"Parents and teachers often notice that children engage in informal math activity while playing freely. Preschoolers explore patterns and shapes, compare sizes, and things count "(Sarama \& Clements, 2009). In early childhood in the Play Group (PG) Istiqamah mathematics is introduced with a variety of fun games, such as the classification of objects in which grouping, sort by certain characteristics. Know the size of large, small-long-short. Know the enumeration that includes words, numbers, children count objects or toys owned. And introduce patterns and shapes, including identification or pattern making, introducing 
geometric shapes through objects in the classroom such as carpets, windows, wall clocks. All math-related things are introduced to children, including introducing geometric shapes. Seo and Ginsburg 2004 argue that preschoolers use, at least intuitively, a more sophisticated geometric concept than most elementary schoolchildren. For example, they often produce symmetry in their game (Sarama \& Clements, 2009).

Methods the introduction of other geometric shapes that can be performed through one of the stimuli that can be given is a tangram game. "Learning using the tangram method can give players (of all ages, both children and adults) a chance to use the game as a prop to form geometric understanding or ideas, as well as develop spatial abilities" (Berutu, 2013).The tangram game consists of a rectangular shape, and a triangle. Through this game, it is expected that children in the Istiqamah Play Group (PG) can get to know other geometric forms. Tangram games according to researchers can be applied to early childhood, because at this age children are in the future.

"Concrete preoperational, Broadly speaking, Piaget categorizes developmental stages into four stages of cognitive maturity in children, sequentially and interrelated, development in the previous stage will affect the next stage "(Rosmalia Septiana, Ratu Ilma Indra Putri, 2003). These stages of development are: (a) Sensorimotor stage 0-2 years, at this stage children begin to show thoughts based on sensory actions; (b) Preoperative stage 2-7 years, children begin to use symbols to show an object and express their thoughts using language; (c) The concrete operation stage of 7-11 years, children begin to use clear and logical rules; (d) Stage of formal operation 11 years - adults, emergence of abstract, hypothetical, deductive, and inductive thoughts. Mathematical games using tangram in children aged 3-4 years namely beginner tangram, which consists of one triangular shape, one rectangular shape and one square shape.

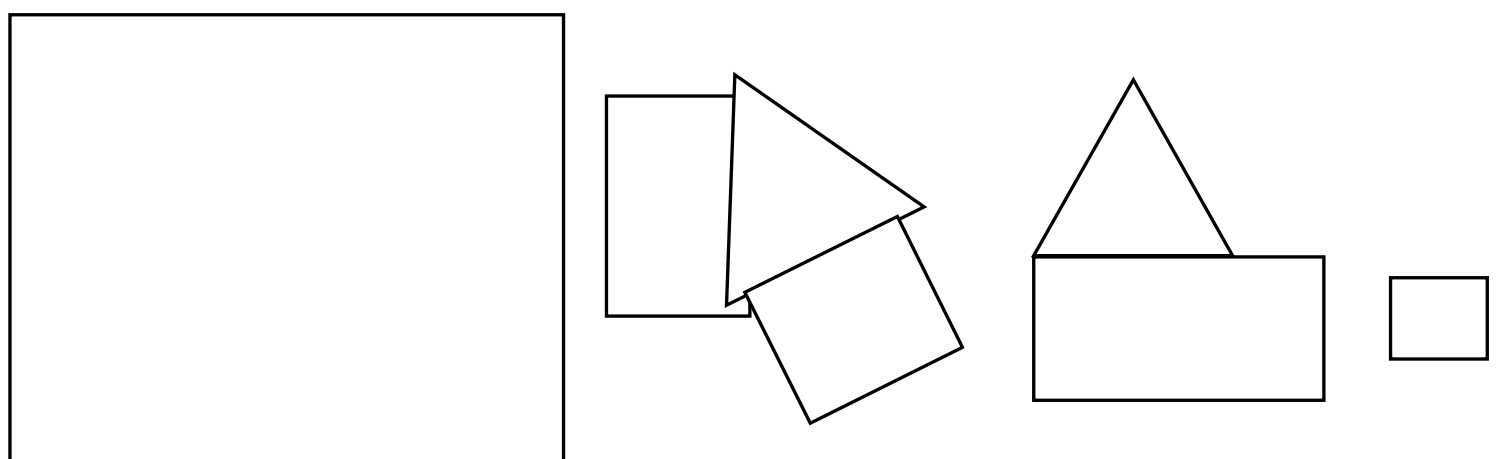

Picture 3. Forms of math games with tangram media for beginners

At this stage it is expected that children can develop well in all aspects of their development, namely the development of moral and religious values, social emotional, language, cognitive, artistic and motoric physical to support at this stage early childhood is expected to develop well in all aspects developments, namely the development of moral and religious values, social and emotional, language, cognitive, artistic and motoric. To support children's development optimally, the right stimulant is needed. It is hoped that by introducing geometric forms through tangram games, cognitive aspects in children are expected to develop optimally. 
From the preliminary results above it can be concluded that the ability to recognize geometric shapes in Istiqamah Playgroup (PG) children is still low. Guidance and motivation are needed in the introduction of geometric forms through fun games. studied using tangram. "According to Bohning and Althouse tangram useful for children in various things, such as; developing a sense of love for geometry; able to distinguish various forms; developing intuitive feelings for forms and geometric relations; developing rotational capability; develop the ability to use appropriate words to manipulate shapes (eg 'flipping', state', 'shift') learn what 'congruent' means (same and concurrent form ')" (Berutu, 2013).

Tangram games can also be an interesting experience for young children. Some language arts activities are centered around tangram, so here inter-disciplinary relations in the field of developing children's abilities, namely language, social-emotional, physical motoric, are more developed. The benefits of drain tangram games make students not feel bored in participating in classroom learning activities because it is fun and challenging, as well as to eliminate verbalism.

The implementation of the repairs was compiled by the researcher in 2 cycles, it is expected that the implementation of these improvements can improve the ability to recognize geometric forms in early childhood in the Istiqamah Play Group. The implementation of the improvement begins with the preparation of planning improvements as outlined in the Daily Learning Plan for three meetings in one cycle, provide learning media, namely tangram consists of one quadrilateral folded piece of paper, one square piece of folding paper and two folding pieces of paper in the form of an equilateral triangle. At the first meeting, the teaching and learning activities began with the initial activities which included activities in class conditioning, motivating and preparing research subjects to take part in learning. This initial activity is continued by explaining the objectives and steps of learning and explaining the steps of learning through the tangram game. Observation activities carried out by researchers as teachers and collaborators during the learning process take place. The observer in this study was a colleague. The Observer at each meeting always observes the researcher using the observation sheet prepared in this study. Observation activities are intended to observe how the learning process and results using the tangram game. The results of observations on the implementation of actions can be described when learning takes place, both children's activities during learning activities and children's responses to learning methods and media. Data retrieval is done by observation and interviews and performance during learning takes place. The results of observations, interviews and performance of children are then reflected to see the extent of the success of the improvements.

The results of improvements in the first cycle showed a significant increase in the ability to recognize geometric forms through the game of tangram. On the ability to mention geometric forms $62 \%$ (good category) of 13 children can mention geometric shapes correctly, there are still $38 \%$ of students not able to correctly mention geometric shapes. In the ability to designate geometric forms there is an increase to $63.5 \%$ which has been able to designate geometric forms correctly there are still $36.5 \%$ of children in the Playgroup (PG) Istiqamah who still need guidance and training in designating forms geometry. In the ability to make more than one geometry form there is an increase of $60 \%$ of children can make more than one geometric shape, there are still $40 \%$ of children who need guidance and practice in making more than one geometric form. Whereas in the ability to tell geometric shapes that were clearly made increased to $65.5 \%$ the child was able to tell the geometric shapes he made clearly. 
The results of the first cycle of reflection are then analyzed to determine the success of this improvement. Conclusion of the results of the first cycle there was a significant increase in the children of the Playgroup (PG) Istiqamah in the introduction of geometric forms through the game of tangram. From the results of observations made, interviews with children and the performance carried out by the children it can be concluded that in mentioning and designating geometric forms it appears to develop according to expectations, making more than one geometric form begin to develop according to expectations and in telling geometric shapes what he clearly made visible began to develop as expected. The results of the first cycle did not meet expectations, because the researchers targeted the Playgroup (PG) children of Istiqamah to get to know geometric forms through tangram games. After the reflection of the results of the first cycle was analyzed the researcher then compiled a plan for improving the second cycle, it was hoped that improvements in the second cycle could improve the introduction of geometric forms of early childhood in playgrup Istiqamah can improve well.

The result of the cycle II improvement plan was prepared by collaborative researchers with teacher observers, researchers compiled an improvement plan as outlined in the Daily Learning Plan three times, providing tangram media made from paperboard with different types and sizes of cycle I, namely two quadrilateral pieces, two pieces square, two sides of an equilateral triangle plus two isosceles triangles. The second cycle meeting begins with. At the first meeting, the teaching and learning activities began with the initial activities which included activities in class conditioning, motivating and preparing research subjects to take part in learning. This initial activity is continued by explaining the objectives and steps of learning and explaining the steps of learning through the tangram game.

The results of the improvement and reflection of the second cycle there was a significant increase in the ability to recognize geometric forms of Istiqamah Playgroup (PG) children namely: the ability to mention geometric forms increased to $93 \%$ of 13 children were able to mention geometric forms well and right. On the ability to show the form $90 \%$ of 13 children have been able to show geometric forms properly and correctly. On the ability to make more than one geometry form increase to $85 \%$ of 13 children can make more than one geometric shape, and on the ability to tell the geometric shapes that they made increased to $87.5 \%$ of children can tell geometric shapes that are made well and clear. The results of the second cycle analysis stated that the tangram game can help early childhood in recognizing geometric shapes, the ability to explore using the tangram game in recognizing geometric shapes is very pleasant for children, especially early childhood.

"Exploration of patterns in tangram games is a key element in mathematics learning. Steen describes mathematics as "science and pattern language", the reasoning of children's mathematics is dependent on their interconnected ability to identify, expand and generalize patterns between the various components of the pattern" (Hutchinson, 2011). Building the concept of geometry in children begins by identifying forms, investigating buildings and separating common images, such as rectangles, circles, triangles, learning the concept of location, as below, above, right, left, laying the foundation for understanding geometry.

\section{CONCLUSION}

Non Formal Education (NFE) is one part of the national education system with a broad and complex scope. Non-formal education or non-formal education is regular and directed communication outside the school and a person gets information, knowledge and skills to 
improve skills for his livelihood. Early childhood education is included in non-formal education or out-of-school education, where early childhood is not yet time to enter formal school but can be equipped with skills and knowledge to improve their abilities to develop optimally including language development, social-emotional, emotional motoric.

Tangram game is one of the games to improve cognitive development of early childhood. Tangram is a game of geometric pieces that are played by arranging the whole piece into a certain shape but each piece cannot overlap each other. Tangram media is easy to play, the color is attractive so children are enthusiastic to play and not bored to play it. This is because the tangram media is easy to play, the color is attractive so the child is enthusiastic to play and not bored to play it so that the child's ability to recognize geometric shapes can develop optimally. Good teacher activities can improve children's abilities. In addition, the tangram media can have a positive impact on the ability to recognize geometric shapes in children's learning programs. This can be proven when the teacher explains the material with clear intonation and expression and explanation of the teacher about using tangram media Gradually and repeatedly, so that the child becomes an understanding and understanding of geometric shapes. In learning that is no less important is the way or rules so that the child's ability to recognize geometric shapes can develop optimally. Based on the research, after data analysis and discussion showed that there was a positive influence in the game of tangram on the introduction of geometric forms in early childhood in the Istiqamah Playgroup (PG). There is an increase in results based on classroom action research conducted in two cycles, it can be concluded that: through the application of game methods can improve the learning process, through the tangram game the introduction of geometric shapes in early childhood in Istiqamah PG increased significantly, seen in the second cycle there was an increase on average to $88.78 \%$. To the teachers, in order to be able to optimize learning activities such as introducing geometric forms by using an interesting game of tangram so that children become more skilled in creating various forms, so as to be able to train dexterity, accuracy and skills of children. Creating an active, creative and fun learning environment. Providing facilities, school facilities and infrastructure, teaching aids, adequate development programs in accordance with the characteristics of child development. To other researchers, in order to be able to conduct further research the problem of using methods and other learning media to be more creative

\section{BIBLIOGRAPHY}

Arikunto, S. (2010). Penelitian Tindakan Kelas, Aksara Jakarta 2010

Berutu, A. (2013). PENERAPAN METODE PERMAINAN DENGAN BERBANTUAN TANGRAM UNTUK MENINGKATKAN HASIL BELAJAR MATEMATIKA PADA MATERI BANGUN DATAR. Jurnal unimed,19 (1), 2013 page 40-47

Hutchinson, E. (2011). PRE-SCHOOL CHILDREN'S UNDERSTANDING OF MATHEMATICAL PATTERNS. Jurnal south african Journal of Childhood Education (SAJCE),1 (2), 2011, page 92-111

Ketut, N,Trisnawati, R.,Wirya, N, Ambara, D.(2014). PENERAPAN METODE BERMAIN BERBANTUAN MEDIA GELOMBANG PINTAR UNTUK MENINGKATKAN PERKEMBANGAN KOGNITIF. e-Journal PG PAUD Universitas Pendidikan Ganesha Jurusan Pendidikan Guru Pendidikan Anak Usia Dini , 2 (1) 2014, page 1-10

Lisa. (2017). PRINSIP DAN KONSEP PERMAINAN MATEMATIKA BAGI ANAK USIA DINI. Jurnal ar-raniry, III tahun 2017, Page 93-103

Rosmalia Septiana,Ratu Ilma Indra Putri,Y.H.(2003). MENGENAL UKURAN DENGAN 
PENDEKATAN PMRI PADA ASPEK KOGNITIF PENDIDIKAN ANAK USIA DINI.

Jurnal unry, VI (2) Desember 2017 ,Page 137-148

Sarama, J., \& Clements, D. D. H. (2009). BUILDING BLOCKS AND COGNITIVE BUILDING BLOCKS: PLAYING TO KNOW THE WORLD MATHEMATICALLY.

Jurnal American Journal of Play. Winter 1(3)2009, page 313-337

Sumardi, Nur, L., \& Sa'diyyah, H. H. (2017). KEMAMPUAN MATEMATIKA ANAK USIA 56 TAHUN DI KOBER AL-HIDAYAH KECAMATAN CIKONENG KABUPATEN CIAMIS. Jurnal PAUD Agapedia, 1(1) Juni 2017, page 106-117 